\title{
Innateness, Philosophical Issues about
}

\author{
Fiona Cowie, California Institute of Technology, Pasadena, California, USA
}

\author{
CONTENTS \\ Introduction \\ Central philosophical issues about innateness \\ Theories of innateness
}

Impact of cognitive science on issues about innateness
Philosophical problems about innateness cover conceptual and empirical issues regarding the claim that concepts or beliefs are innate, inborn, or genetically determined.

\section{INTRODUCTION}

0167.001 Many different kinds of traits are claimed to be innate in us and other animals. We speak of a termite's innate nest-building behavior, a llama's innate hairiness, a German Shepherd dog's innate tendency to hip dysplasia, a person's innate beauty. Philosophical interest in innateness, however, has centered around the innateness or not of various mental properties. Probably because of the issue's traditional connections with epistemological problems like justification and a priori knowledge, philosophical attention has focused on the innateness (or not) of our 'ideas' or representations (e.g. concepts and beliefs) and, to a lesser extent, our cognitive abilities (e.g. mechanisms of learning). This article, too, will focus on the innateness of mental items (ideas or capacities) rather than physical features or behaviors.

The first known philosophical claims about the innateness of concepts and beliefs were made by Plato (428-348 вс) in his dialogues Phaedo (74b-75e) and Meno (80d-e). (See Grube, 1997.) He argues (in the voice of Socrates) that since some of the concepts and knowledge we possess could not have entered the mind through sense experience or as a result of teaching, they must be innate, that is acquired by our souls prior to our birth. So-called learning, he argues, is really a process of recollection: our experience reminds us of things we already know but have forgotten. Later defenders of the view that certain ideas are innate include the philosophers René Descartes (1596-1650), Gottfried Leibniz (1646-1716), and Immanuel Kant (17241804). Most recently, two cognitive scientists, the linguist Noam Chomsky and the philosopher Jerry Fodor, have taken up arms under the nativist banner: Chomsky defending the notion that our knowledge of language is substantially innate, and Fodor arguing that the vast majority of our concepts are innate (e.g. Chomsky, 1986 and 1990; Fodor, 1981 and 1998). Notable critics of these various 'innateness hypotheses' have included the historical figures Aristotle (384-322 вс), John Locke (1632-1704), and David Hume (1711-1776).

\section{CENTRAL PHILOSOPHICAL ISSUES ABOUT INNATENESS}

The central philosophical question - indeed, the 0167.003 central question about innateness is: what, if anything, is innate? To aid in answering this question, philosophers have asked a prior question: what is innateness and why should we care about it? Then, to help in answering this question, they have further inquired: what do particular nativists (i.e. defenders of an innateness hypothesis) mean when they call some idea or capacity 'innate'? Thus, the three main philosophical issues about innateness are:

1. the interpretive issue: what do nativists mean by the claim that such and such mental item is innate?

2. the explanatory issue: what is innateness, and what does an idea's being innate enable us to explain?

3. the factual issue: which ideas (concepts, beliefs, knowledge) and cognitive or behavioral capacities are innate?

The interpretive issue arises because it is frequently 0167.004 very difficult to tell exactly what a person means when she claims that certain ideas are innate. People often appeal to metaphors and analogies in explaining what innateness is, and these often support conflicting interpretations. For example, Descartes sometimes says that concepts or beliefs are innate in the same way that certain diseases (like gout) are innate in certain families (Descartes, 1985). This argument, together with the fact that many of the concepts and beliefs he discusses are 
not possessed by babies or very small children, suggests that in his view, innate concepts or beliefs are not present at birth but exist as potentialities or dispositions to acquire ideas during the course of development. (See Stich, 1975.) Chomsky, by contrast, claims that principles of Universal Grammar (UG) are innately represented in the human 'language organ' and are crucially implicated in the process of language acquisition. This assertion suggests that, for Chomsky, innate knowledge of UG is no mere disposition but is encoded in the brain at birth in a robust and causally efficacious form. Fodor (1981), to take another example, has likened innate concepts to imprinted behaviors, suggesting that for him, innate ideas are not learned but are merely 'triggered' by some appropriate releasing stimulus. It is unclear that the same or even a similar notion of innateness is at work in these three authors, and the interpretive problem only increases as the work of additional nativists is examined. (See Cowie, 1999, ch. 1, for more on the interpretive issue.)

0167.005 While it is, of course, important to understand what theorists (past or present) have thought about innateness, the interpretive issue is primarily of interest to cognitive science because it bears on (2), the explanatory issue. Innateness is most commonly invoked to explain how an idea was acquired: Meno's untutored slave knows Pythagoras's theorem because it is innate; we know that $2+2=4$ because we have innate knowledge of mathematics; people believe in God because of an innate concept of the deity. The fact that innate ideas are often contrasted with those that are learned or otherwise acquired as a result of experience has led to the notorious 'nature versus nurture' debate about whether our genes or our experience are responsible for our mental lives. This debate is generally fruitless for two reasons. First, everyone knows that both experience and the genes are implicated in cognitive development: the opposition between nature and nurture is overstated. Second, participants in nature versus nurture debates often talk past one another, simply because there are so many different understandings of innateness at play in the literature. In order to avoid such unproductive arguments, therefore, is vital to be very clear about what notion of innateness is being used in a specific discussion. For example, it would be a serious mistake to read Fodor's claim that most concepts are innate as asserting (in Cartesian vein) merely that we have dispositions to acquire concepts during the course of development. The latter claim, while true enough, trivializes what is meant to be a substantive - indeed, radical - claim about concept acquisition, because it is quite consistent with the typical empiricist's view that concepts are learned. ('Empiricist' is the name given to opponents of innate ideas.)

The explanatory issue thus arises in part because 0167.006 the interpretive issues are not clear. In discussing the innateness of various concepts, beliefs, or capacities we need to be explicit about what notion of innateness we are invoking. We also need to be clear about why that notion is important: we need to understand what innateness, so understood, explains. For too often it is assumed that the innateness of a trait has implications which, upon examination, it does not have. Herrnstein and Murray (1994), for instance, argue that IQ is substantially innate and that certain ethnic groups are inherently deficient in intelligence, concluding thence that social and educational programs aimed at those groups are ineffective. But as Block (1995) has responded, since 'innate' for Herrnstein and Murray means something like 'highly heritable', this conclusion does not follow even if the facts are as they claim. For the heritability of a trait is a measure of the extent to which variance in the trait in a population is correlated with genetic (as opposed to environmental) variation, and high heritability does not imply imperviousness to (or even difficulty of) change by means of environmental manipulations. In the next section of this article, we will look at a number of different notions of innateness used in the contemporary and historical literatures and examine their explanatory abilities.

Once one has clarified one's explanatory goals 0167.007 and chosen an appropriate notion of innateness, the question arises: what traits, if any, are innate (in that sense)? This is the third, the factual issue, about innateness with which philosophers have been concerned. In the final section, we will look at what sorts of evidence bear on this factual question, focusing in particular on the ways in which cognitive science plays a role in determining which of our ideas are innate.

\section{THEORIES OF INNATENESS}

Philosophical investigations of innateness have 0167.008 revealed that there are about as many different things meant by the claim that an idea is innate as there are theorists making such claims. In this section, we will survey some of these different notions of innateness and see what sorts of explanations they figure in. 


\section{'Innate' means 'built in' or 'inborn'}

0167.009

When the person in the street talks of hearts or hands or hemophilia being innate, what she often means to indicate is that those features are 'built in' or present at birth, the intended contrast being with traits that are acquired as a result of our postnatal experiences in the world. Arguably, some mental (e.g. some perceptual and inferential abilities) must be innate in this sense, or we would have no mental lives at all. However, there is room for considerable controversy about what else may be inborn. For example, Locke (1975) famously argued (contra Leibniz, 1981) that no beliefs are inborn, since infants are not conscious of them and cannot make use of them but must learn them as a result of experience. Currently, cognitive scientists are debating the extent to which knowledge of language is inborn (see Pinker, 1994; cf. Cowie, 1999), and neuroscientists are debating the extent to which the organization of the brain is inborn rather than being fixed by experience (e.g. Quartz, 2002.)

\section{'INNATE’ MEANS 'GENETICALLY DETERMINED'}

0167.010 Since the discovery of genes as the mechanisms of inheritance, talk of innateness has sometimes been code for the genetic determination of traits. When we say that a tendency to violence, or dyslexia, or the capacity for shared attention is innate, we may mean that it is under the control of one or more specific genes. Here, the aim is to explain such facts as why some traits seem to run in families, and/or why they seem to develop reliably under many different circumstances, and/or why they seem independent of other cognitive capacities, and/or why they seem impervious to ordinary environmental interventions (e.g. coaching or therapy). A major problem with the use of 'innate' in this sense, whether in cognitive science or elsewhere, is that the concept of genetic determination on which it is based is itself extremely unclear. If, for instance, a trait counts as genetically determined so long as there are genetic necessary conditions for its development, then arguably all traits are genetically determined, hence innate. If, instead, genetic determination requires that there be genetically sufficient conditions for the trait, then arguably nothing is genetically determined, since the survival of any organism requires certain environmental conditions to obtain. If genetic determination is relativized to a certain class of environments (by saying, e.g. that a trait is genetically determined if, given a normal environment, its development is controlled by the genes), then its meaning changes as the class of relevant environments does. And if genetic determination requires that there be particular genes which are 'the cause of' or are 'responsible for' a given trait, then it is at least unclear that many traits - especially those of interest to cognitive science would be candidates for innateness. First, many genes are implicated in the development of many different traits - regulatory genes are one example; certain hox genes, which are expressed in both the fore- and hindlimbs of tetrapods are another. Second, the development of most traits requires the coordinated activity of many different genes. So while development can certainly be disrupted by 'knocking out' one or more of these genes (as, e.g. deletion of the ultrabithorax gene in fruitflies causes two copies of the second thoracic segment, including wings, to develop), it cannot be inferred from this that those genes are the 'causes of' the trait in any more robust sense than ambient oxygen is 'the cause of' a wildfire. (See Davidson, 2001; Block, 1995; Kitcher, 1985 for more on genetics and genetic determination.)

\section{'Innate' means 'has a flat norm of reaction'}

One way of making more precise the idea that 0167.011 innate traits are those which are genetically determined is by invoking the notion of a norm of reaction. A norm of reaction is a function which describes how a phenotypical property, P, varies in response to environmental variation in organisms with a given genotype, G. P is said to have a 'flat' norm of reaction when there is little or no change in $\mathrm{P}$ across different environments, and this is of interest because the traits we call 'genetically determined' or 'innate' often display this feature. Thus, for instance, hair is both innate and (pretty much) inevitable in mammalian genotypes, as are feathers in avian ones, and backbones in vertebrate ones. It is not clear, however, that this is a useful sense of innateness when speaking of ideas. There are many ideas which are inevitable, yet not innate, being a result rather of ubiquitous features of the environment. For instance, overwhelmingly, most people who survive at all have the concept 'water' and the belief that night follows day.

\section{'Innate' means 'canalized'}

A related, highly precise view of innateness in- 0167.012 volves the biological concept of canalization. A 
trait is said to be canalized when its development is buffered against certain environmental and genetic variations (Waddington, 1942). Brains, for example, have this feature: most mutations and most environmental changes do not prevent their development. The philosopher Andre Ariew (1996, 1999) has argued that the best account of innateness holds a trait to be innate (in a given range of environments) to the extent that its development is canalized (in that range). Innateness in this sense, as he notes, enables us to explain why certain traits appear so reliably in a population. What is problematic for this proposal, however, especially as an account of what 'innate' might mean for cognitive scientists, is that many ideas seem to be canalized without being plausibly called innate. Again, the belief that night follows day and the concept 'mother' are examples.

\section{'Innate' means 'genetically entrenched'}

0167.013 Another philosophical account of innateness is due to the philosopher William Wimsatt. He argues (e.g. 1986, 1999) that innate traits are the ones that are highly 'generatively entrenched'. Generative entrenchment is a measure of what one might call 'ontogenetic necessity'. The more entrenched a property or process is, the more disruptive to subsequent development is its absence or modification:

to be innate is to be deeply generatively entrenched in the design of an adaptive structure - to be a functional part of the causal expression of that system...upon which the proper operation of a number of other adaptive features depends. (Wimsatt, 1999, 153)

0167.014 Thus, having a brain is in his view a deeply entrenched or innate property: modifications to that organ cause a cascade of other developmental effects. Some problems with this account of innateness are (i) it does not capture the opposition with learning that is so crucial to many discussions of innate ideas, since learned ideas can be highly entrenched precursors to the acquisition of other adaptive cognitive structures; (ii) it apparently counts environmental features as innate if it turns out that they are necessary to further development. (E.g. having edges or lines of different orientations in the visual environment would be an innate trait of Hubel and Wiesel's famous kittens, since normal visual development was found to be contingent on experience of those stimuli.)

\section{'Innate' means 'developmentally constrained'}

Elman et al. (1996) have proposed that innateness 0167.015 be understood in terms of the notion of developmental constraints. In their view, ideas and behaviors count as innate to the extent that there are constraints on (i) the representational systems they involve, and/or (ii) the architectures that implement them, and/or (iii) the timing of their development. The more constraints there are operating at any of these levels, the more the trait counts as innate. Elman et al. maintain that their notion of innateness is of interest to cognitive science because it recognizes the complex interplay of genome and environment during development, thus avoiding spurious arguments about 'nature versus nurture'. However, it is difficult to see what innateness, so understood, explains. Since the development of every trait is multiconstrained, not just by environmental conditions and genes of various sorts but also by myriad other factors (such as the laws of physics and chemistry, the plasticity of the relevant portion of the genome, the existence and fitness of alternative phenotypes), all traits would appear to be to some extent innate, in this view.

\section{'Innate' means 'triggered' or 'not learned'}

The philosopher and cognitive scientist Jerry Fodor 0167.016 seeks to import the notion of triggering (Lorenz, 1965) into discussions of innate ideas. He argues $(1981,1998)$ that most concepts are innate in us in the same way as imprinting is innate in ducklings: just as a duckling's attachment to its mother is triggered by its first visual and auditory experiences of her, our concepts are triggered by our experiences of their instances. Here, the intended contrast is with learning: just as ducklings don't learn to love their mothers, we don't learn concepts - even concepts like 'train' and 'rose' are unlearned, in Fodor's view. A problem with this proposal is that triggering is in most cases a poor model for the process of concept acquisition. First, the connections between releasing stimuli and triggered behaviors are set up by natural selection, but natural selection has not had time to set up connections between many concepts (e.g. train) and the world. Second, whereas there is typically a critical period for the development of triggered responses, there appears to be no critical period for the acquisition of concepts like train. Finally, and because behaviors and releasing stimuli are paired by natural selection, the stimuli for triggered behaviors 
are arbitrary in a way that the experiences leading to acquisition of a concept are not. There is no intrinsic connection between red spots and sex, yet natural selection has recruited red spots as a trigger for mating behavior in stickleback fish. In contrast, there is an intrinsic connection between concepts and the experiences that cause their acquisition: 'rose' is acquired as a result of seeing, or hearing talk about, or reading about roses.

\section{IMPACT OF COGNITIVE SCIENCE ON ISSUES ABOUT INNATENESS}

0167.017 It remains to consider the factual issue about innateness, and this is where the various branches of cognitive science play a crucial role.There are three main types of argument used in support of innateness hypotheses. These are:

- Transcendental arguments.

- Poverty of the stimulus arguments

- Impossibility arguments.

0167.018 The soundness of these arguments clearly depends on what sense of 'innate' is being invoked. Transcendental arguments (Antony, 1999) concern innateness in the sense of 'inborn' or 'present at birth'. They point out that in order for learning from experience to be possible at all, something must be there already. Even the most extreme empiricists accept the conclusion of transcendental arguments; where they differ from nativists is in their accounts of what is inborn. Empiricists like the behaviorist B. F. Skinner think that all that is innate are dispositions to emit certain behaviors as a result of certain environmental stimuli, together with a disposition to modify the strength of these stimulus-response connections in response to reinforcement. In contrast, a nativist like Chomsky thinks that knowledge of UG is inborn. This is a much stronger innateness hypothesis than Skinner's, since it requires that there be inborn syntactic representations. Cognitive science contributes to this debate primarily by clarifying the processes of cognitive development. For only when we know what the mechanisms of learning and development are will we be in a position to identify their inborn precursors.

0167.019 Poverty of the stimulus arguments contends that a given idea (a belief or a concept) must be innate (again in the sense of 'inborn') because because the environment does not provide enough information to enable it to be learned. For example, Chomsky has argued that since the information about language available to children is so meager, knowledge of language must be substantially innate - in particular, he argues, a representation of Universal Grammar, a theory describing the features shared by all human languages, is an inborn feature of the 'language acquisition device'. (e.g. Chomsky, 1965 and 1993.) Poverty of the stimulus arguments relies on four crucial empirical premisses: (i) people do in fact possess the idea in question (e.g. people have knowledge of a generative grammar); (ii) the available information is of such and such kinds (e.g. children do not get evidence about what not to say); (iii) the available learning mechanisms are of such and such types (e.g. language learning proceeds by hypothesis testing); (iv) the available information is not sufficient to enable the idea to be learned by that learning method. Cognitive science will be critical in verifying all these premisses. For example, psycholinguistic theories of the processes of language production and comprehension will be the ultimate arbiters of Chomsky's claim that language use and understanding involve knowledge of a generative grammar; developmental psychology will tell us what information, as a matter of fact, children learning language have access to; and cognitive psychology or cognitive neuroscience, perhaps, will tell us what are the learning methods available to them. Only then will it be clear whether innate knowledge of UG is required for language acquisition.

A third kind of argument for innate ideas claims 0167.020 that since learning a certain idea is literally impossible, that idea must be innate. Fodor is the contemporary champion of this form of argument, contending that since concept learning is impossible, concepts must be innate. Fodor's impossibility argument starts with a transcendental point. Since learning a concept involves formulating and testing hypotheses about what it means, we must already have some representations available to use in stating our initial semantic hypotheses: unless some concepts are innate, concept learning could never get off the ground at all. Fodor's impossibility argument then continues as follows. Successful learning of a concept involves finding the correct hypothesis about what it means. This requires that we find, in effect, the definition of the concept: we have learned the concept 'dog' when we know that dog applies to a thing if and only if that thing is $\mathrm{F}$, where F specifies the necessary and sufficient conditions for doghood. However, Fodor contends that, since most concepts don't have definitions (in the sense that we cannot specify their necessary and sufficient conditions, except circularly, by using the very concepts at issue), most concepts could not be learned. Concept learning is (in most cases) impossible, so most concepts must be innate. 
0167.021

It is still unclear exactly what 'innate' means in the context of Fodor's impossibility argument there is still a serious interpretive issue here (see Cowie, 1999, ch. 4). However it is clear, whatever 'innate' turns out to mean for Fodor, that cognitive science has an important role to play in establishing the soundness this argument. First, by developing alternatives to the hypothesis-testing model of concept acquisition, cognitive science may undermine the transcendental argument with which Fodor's argument begins: maybe concept learning does not require that we already have representations (though it may require that we have, say, a neural network with a certain kind of distribution of initial weights and a certain learning algorithm). Second, the development of alternatives to Fodor's account of concept possession may undermine his argument from the indefinability of concepts to their unlearnability. If having a concept is not necessarily a matter of knowing the necessary and sufficient conditions for its application (as, e.g. Prinz, 2002, argues), then the indefinability of concepts is no bar to their being learned.

0167.022 In sum: claims about the innateness of ideas are often ambiguous. In order to assess such claims, then, it is necessary to understand what sense of 'innate' is being used and to be clear about what innateness, so construed, can explain. Claims about the innateness of ideas are also subject to empirical test, and this is where cognitive science comes in. When the processes of learning and development are better understood, we will be in a better position to know what is innate, and what this might mean.

\section{References}

Antony LM (2001) Empty heads. Mind and Language, 16. Ariew A (1996) Innateness and canalization. Philosophy of Science 63: S19-S27.

Ariew A (1999) Innateness is canalization: in defense of a developmental account of innateness. In: Hardcastle V. (ed.) Where Biology Meets Psychology: Philosophical

Essays, pp. 117-138. Cambridge, MA: Bradford Books / MIT Press.

Block N (1995) How heritability misleads about race. Cognition 56: 99-128.

Chomsky N (1965) Aspects of the Theory of Syntax, Cambridge, MA, MIT Press.

Chomsky N (1986) Knowledge of Language, Its Nature, Origin and Use. New York: Praeger.

Chomsky N (1988) Language and Problems of Knowledge,

The Managua Lectures. Cambridge, MA: MIT Press.

Chomsky N (1990) On the nature, use and acquisition of language. In: Lycan WG (ed.) Mind and Cognition: A Reader, pp. 627-45. Oxford: Blackwell.
Chomsky N (1993) Language and Thought. Wakefield, RI and London: Moyer Bell.

Cowie F (1999) What's Within: Nativism Reconsidered New York: Oxford University Press.

Davidson ER (2001) Genomic Regulatory Systems:

Development and Evolution. San Diego: Academic Press.

Descartes R (1985) Comments on a certain broadsheet. In: Cottingham J, Stoothoff R and Murdoch D (eds and trans.) The Philosophical Writings of Descartes, vol. I, Cambridge, UK: Cambridge University Press.

Elman JL, Bates EA, Johnson MH, Karmiloff-Smith A, Parisi D and Plunkett K (1996) Rethinking Innateness: A Connectionist Perspective on Development. Cambridge, MA: Bradford Books/MIT Press.

Fodor JA (1981) The present status of the innateness controversy. In: RePresentations: Philosophical Essays on the Foundations of Cognitive science, pp. 257-316.

Cambridge, MA: MIT Press/Bradford Books.

Fodor JA (1998) Concepts: Where Cognitive Science Went Wrong. New York: Oxford University Press.

Grube GMA (1997) (trans.): Meno and Phaedo. In: Cooper JM and Hutchinson DS (eds) Plato: Complete Works. Indianapolis: Hackett.

Herrnstein RJ and Murray C (1994) The Bell Curve. New York: Free Press.

Kitcher P (1985) Vaulting Ambition: Sociobiology and the Quest for Human Nature. Cambridge, MA: MIT Press.

Leibniz WG (1981) New Essays on Human Understanding, translated by P Remnant and J Bennett. Cambridge, MA: Cambridge University Press.

Locke J (1975) An Essay Concerning Human Understanding, edited by PH Nidditch, Oxford: Oxford University Press.

Lorenz KZ (1965) Evolution and the Modification of Behavior Chicago: University of Chicago Press.

Pinker S (1994) The Language Instinct: How the Mind Creates Language. New York: Harper.

Prinz JJ (2002) Furnishing the Mind: Concepts and Their Perceptual Basis. Cambridge, MA: MIT Press.

Quartz SR (2002) Learning and brain development: a neural constructivist perspective. In: Quinlan P (ed.) Connectionist Models of Development. New York: Psychology Press.

Stich SP (1975) Introduction. In: Stich SP (ed.) Innate Ideas, Berkeley: University of California Press.

Waddington CH (1942) Canalization of development and the inheritance of acquired characteristics. Nature 150: 563.

Wimsatt WC (1986) Developmental constraints, generative entrenchment and the innate-acquired distinction. In: Bechtel W (ed.) Integrating Scientific Disciplines, pp. 185-208, Dordrecht: Martinus-Nijhoff.

Wimsatt WC (1999) Generativity, entrenchment, evolution and innateness: philosophy, evolutionary biology, and conceptual foundations of science. In: Hardcastle V (ed.) Where Biology Meets Psychology: Philosophical Essays, pp. 139-179, Cambridge, MA: Bradford Books/MIT Press. 


\section{Further Reading}

Barkow JH, Cosmides L and Tooby J (1992) The Adapted Mind: Evolutionary Psychology and the Generation of Culture. New York: Oxford University Press.

Chomsky N (1988) Language and Problems of Knowledge, The Managua Lectures. Cambridge, MA: MIT Press.

Cowie F (1999) What's Within? Innateness Reconsidered.

New York: Oxford University Press.

Elman JL, Bates EA, Johnson MH, Karmiloff-Smith A,

Parisi D and Plunkett K (1996) Rethinking Innateness: A Connectionist Perspective on Development. Cambridge, MA: Bradford Books/MIT Press.

Fodor JA (1998) Concepts: Where Cognitive Science Went Wrong. New York: Oxford University Press.

Griffiths P (2002) What is innateness? Monist 85: 70-85.

Kitcher P (1985) Vaulting Ambition: Sociobiology and the

Quest for Human Nature. Cambridge, MA: MIT Press.

Pinker S (1994) The Language Instinct: How the Mind

Creates Language. New York: Harper.

Pinker S (1997) How the Mind Works. New York: W.W.

Norton.

Prinz JJ (2002) Furnishing the Mind: Concepts and Their Perceptual Basis. Cambridge, MA: MIT Press.

Quartz SR and Sejnowski TJ (1997) The neural basis of cognitive development: a constructivist manifesto. Brain and Behavioral Sciences 20: 537-596.

Stich SP (ed.) (1975) Innate Ideas, Berkeley: University of California Press.

\section{Glossary}

Empiricists Those who deny innateness hypotheses.

Genetic Entrenchment The extent to which subsequent development depends on a given developmental process or result.

Heritability The ratio of the total genetic variance to the total phenotypic variance.

Ideas A somewhat archaic term for mental representations, e.g. concepts or beliefs, commonly used in the innateness literature, as in 'innate ideas'.

Innateness hypothesis An hypothesis about what ideas or capacities are innate.

Imprinting The process by which some animals form an attachment to other animals.

Nativists Defenders of innateness hypotheses.

Nature versus nurture controversy The debate about whether our genes or our experience are responsible for our mental lives.

Norm of reaction The range of phenotypes expressed by a given genotype across different environmental conditions.

Triggering A relatively automatic and stimulus-driven process, to be contrasted with that of learning, by which ideas or behaviors may be acquired from experience.

Keywords: 
ECSarticle167

1. Impossibility arguments, para 1, Antony 1999 but 2001 in refs

2.References - Antony, need page nos.

3. Fodor 1981 - name of editor?

4. Can you supply five keywords characterizing your article? 